\title{
Pacto Educativo Global: semente para florescer um novo tempo
}

Eduardo Brasileiro ${ }^{1}$

Em 2021, em meio ao aprofundamento da reflexão e vivência sob o Pacto Educativo Global, celebramos também o centenário do educador Paulo Freire (Recife - 1921, São Paulo - 1997). Feliz encontro, pois, a memória e a reflexão sobre Paulo Freire devem ter uma peculiaridade. Quero dizer que não se trata de pensar miudamente práticas específicas de educação com base nas ideias de Paulo Freire. Isto negaria o próprio Paulo Freire pela essência. Nada menos freiriano do que ser seguidor de ideias sem saber ser criador de espíritos. Trata-se de criarmos condições para estarmos pondo fraternalmente à prova a nossa própria capacidade de criar. De ousar mesmo. De abrir horizontes como um fertilizador do inusitado (Brandão, 1992).

O pacto educativo global foi divulgado, não inocentemente, a partir de um antigo saber popular africano: "Para educar uma criança é preciso uma aldeia inteira". Quem é essa aldeia inteira? Pensar essa "inteireza" é fazer como Paulo Freire fazia ao brincar com a palavras para desenhar novos cenários possíveis.

O grande desafio reside nessa compreensão do que é o inteiro, o completo, o integral. Existem realidades distintas sobre uma estrutura social única, em que todas as reflexões apontam para uma revisão do projeto civilizador e a importância da energia revolucionária de se propor uma nova civilização. Por isso, a educação vai nos convocar a um mergulho no ser humano integral. O humano integral é um ser ecológico (Francisco, 2015). Fruto da educação comunitária plural, grávida de expressões ancestrais, culturais e sociais. O ser ecológico é nosso encontro com uma economia da partilha, da política da solidariedade, da vivência-comunitária como percurso de aprendizagem para comunidades-inteiras. Comunidades onde se viva de modo economicamente sustentável,

\footnotetext{
${ }^{1}$ Eduardo Brasileiro, mestrando em sociologia (PPGCS - PUC MG) e educador na periferia de São Paulo. Integra a Articulação Brasileira pela Economia de Francisco e Clara (ABEFC), integra o Nesp (Núcleo de Estudos sociopolíticos) da PUC Minas. Compõe a Articulação Brasileira pelo Pacto Educativo Global e participou do encontro "Educadores para a Cultura do Encontro com o Papa Francisco" em março de 2018 em Roma.
}

DIGNIDADE RE-VISTA | ISSN2525-698X| 2021 | V. VIII | N. 13 |Pacto Educativo Global: a busca por ressignificar a educação. Pastoral Universitária Anchieta PUC-RIO. 
sem pessoas desempregadas e passando fome, onde a prática política é presente no areópago comunitário.

Esses dois irmãos-nossos latino-americanos possuem a característica de chamar a educação como ferramenta do encontro. É o encontro efetivo com os corpos marginalizados e descartáveis que permite nos alfabetizarmos pelo olhar do outro. Francisco a nomina como Cultura do encontro, pedagogia forjada no ato de viver a proximidade com os descartáveis, pelo discernimento coletivo e pela delimitação do conflito. Mover-se pela solidariedade exigirá conflito, mas, ao mesmo tempo, perfaz um novo corpo de uma política solidária em oposição à atual.

Um compromisso fundamental a ser abraçado por todas as pessoas que mergulham nessa edição da Dignidade Re-vista é se somar ao papa Francisco para "realmar" a realidade vivida, propondo uma dissociação de uma sociedade governada por um sistema econômico, se permitir uma transição socioecológica vivida pela fraternidade universal a partir de novos parâmetros econômicos e políticos. Assim também podemos fazer se assumirmos nosso papel de educadores e educadoras: "realmar" as relações.

Francisco e Freire são acendedores da brasa do comum. E nos presenteiam a chance de fazermos nós também contracondutas, que nos alimentam para enfrentamento ao capitalismo desenhando novas arquiteturas socioeconômicas. Ambos possuem uma dimensão dialógica com o seu tempo, movidos pela percepção ética forte do que entendemos p mutirão. Isto é, as mãos juntas são fortes porque são juntas, não porque são mãos. E a "juntidade" - para usar uma expressão que Freire usaria - dessas mãos é que faz a força. É assim que percebemos que o pacto educativo não nasce de nós, ele está vivo em nossas comunidades a partir do encontro com os coletivos culturais, com os quilombos periféricos, com as organizações feministas, com as associações comunitárias, com as economias solidárias, entre outras, que emanam o sopro do Espírito de Deus e anunciam outros mundos possíveis. 